\title{
ХАРАКТЕР ЦИРКАДНОЇ І ВЕГЕТАТИВНОЇ РЕГУЛЯЦЇ̈ АРТЕРІАЛЬНОГО ТИСКУ В ЖІНОК ІЗ ГІПЕРТОНІЧНОЮ ХВОРОБОЮ ЗАЛЕЖНО ВІД НАЯВНОСТІ СУПУТНЬОЇ ЗАЛІЗОДЕФІЦИТНОЇ АНЕМІї, Iї̈ ТЯЖКОСТІ І ТРИВАЛОСТІ
}

\author{
Вінницький національний медичний університет ім. М.І. Пирогова
}

\begin{abstract}
Резюме. Обстежена 141 жінка із гіпертонічною хворобою II стадії з та без супутньої залізодефіцитною анемією віком від 54 до 87 років. У пацієнток вивчали характер циркадної та вегетативної регуляції артеріального тиску (АТ) залежно від наявності супутньої залізодефіцитної анемії, іiі тяжкості і тривалості. Проводився аналіз результатів активної ортостатичної проби і добового моніторування АТ з розрахунком загальновідомих показників. Виявлено, що наявність супутньої залізоде-
\end{abstract}

фіцитної анемії та ії тяжкість у жінок із гіпертонічною хворобою асоціює зі значними порушеннями добової регуляції АТ і його барорефлекторної регуляції. У свою чергу, не виявлено значущих асоціацій між тривалістю супутньої анемії і порушеннями циркадної регуляції АТ.

Ключові слова: циркадна регуляція і циркадний профіль артеріального тиску, гіпертонічна хвороба, залізодефіцитна анемія.

залежно від наявності супутньої ЗДА, її тяжкості і тривалості.

Матеріал і методи. Обстежена 141 жінка із ГХ ІІ стадії з та без супутньої ЗДА віком від 54 до 87 (у середньому 69,47 $\pm 0,81$, медіана - 69, інтерквартильний розмах - 62 і 78) років. Обстеження пацієнтів проведено на базі міської клінічної лікарні №1 м. Вінниці. Критеріями включення в дослідження були: ГХ ІІ стадії за рекомендаціями ESH/ESC, 2013 і чинного наказу №384 від 24.05.2012 з та без супутньої ЗДА (рівень гемоглобіну крові $\leq 110$ г/л $і$ кольоровий показник < 0,85 , рівень заліза сироватки $<8$ мкмоль/л $i$ феритину < 15 мкг/л) за рекомендаціями $[2,6]$; жіноча стать; відсутність ефекту (рівень АТ > 140/90 мм рт. ст.) попереднього антигіпертензивного лікування та необхідність брати участь у дослідженні і застосовувати запропоноване лікування. Критеріями виключення із дослідження були: чоловіча стать; ГХ ІІІ стадії та симптоматичні АГ; анемії тяжкого ступеня (гемоглобін крові < 70 г/л), нормо- та гіперхромні анемії (кольоровий показник $\geq 0,85$ ); великі хірургічні втручання за останні шість місяців, які могли призвести до значної крововтрати; супутні захворювання дихальної системи та шлунково-кишкового тракту, які потребували активного лікування; порушення серцевого ритму та провідності, які потребували постійного антиаритмічного лікування або імплантації електрокардіостимулятора; зловживання алкоголем та тяжкі нейропсихічні розлади. Розподіл пацієнтів на різні клінічні групи проводився за наступним принципом: 1) за наявністю та відсутністю супутньої ЗДА; 2) за тяжкістю (ступенем) супутньої ЗДА і 3) за тривалістю анемічного анамнезу.

Обстеження осіб включало загальноприйняті методи дослідження і оцінку показників обміну заліза (рівень гемоглобіну, сироваткового заліза і феритину, кольорового показника). Аналіз циркадної і вегетативної регуляції АТ проводили на основі результатів добового моніторування АТ 3 
розрахунком загальновідомих показників і активної ортостатичної проби $[1,5]$. Остання характеризувалася вимірюванням АТ на 3-й хвилині після переходу пацієнток із горизонтального (перебували не менше 10 хвилин) у вертикальне положення, що свідчило про характер реакції систолічного АТ на зміну положення тіла і надавало можливість оцінювати характер барорефлекторної регуляції судинної системи.

Статистичну обробку результатів дослідження проводили за допомогою методів варіаційної статистики 3 використанням програми StatSoft „Statistica” v. 10.0 згідно з рекомендаціями [3, 4]. Отримані результати представлені: 1) кількісні величини - у вигляді медіани і інтерквартильного розмаху (25 і 75 процентилі) і 2) відносні величини (відображали частоту ознаки у вибірці) у вигляді відсотків (\%). Порівняння відносних величин (\%) проводили за допомогою критерію $\mathrm{x}^{2}$, кількісних величин незалежних вибірок - за медіанним критерієм та критерієм Манна-Уітні.

Результати дослідження та їх обговорення. Аналіз даних добового моніторування АТ і ортостатичної проби в жінок із ГХ залежно від наявності супутньої ЗДА (табл. 1) показав, що анемія асоціює із суттєвим зростанням величини систолічного АТ (САТ) за всі проаналізовані періоди доби. Нами зареєстровано збільшення величини середньо-добового (САТ_доб., $\mathrm{p}=0,022$ ), середньо-денного (САТ_ден., p=0,020) i середньонічного САТ (CAT_ніч., $\mathrm{p}=0,029$ ) у жінок із ЗДА порівняно з групою без анемії. Крім того, визначено суттєве збільшення величини індексу варіабельності САТ у денний час (IB CAT, p=0,029), швидкості ранкового приросту САТ (ШРП САТ, $\mathrm{p}=0,032)$ і індексу часу САТ протягом доби (IЧ CAT, p=0,003). Крім змін з боку САТ, реєстрували суттєве збільшення величини діастолічного (ДАТ_ніч., p=0,041) і пульсового АТ (ПАТ_ніч., $\mathrm{p}=0,0 \overline{3} 8)$ у нічний час. Відомо, що саме визначені характеристики АГ виступають як найбільш небезпечні чинники ризику різних серцевосудинних катастроф, у тому числі і фатальних. Отже, виходячи $з$ отриманих даних, слід думати, що супутня ЗДА у хворих на АГ асоціює 3 більш небезпечними у прогностичному плані характеристиками АГ, що може збільшувати ризик розвитку різних серцево-судинних ускладнень у цих пацієнтів.

Оцінка результатів реакції САТ на активну ортостатичну пробу показала, що абсолютна величина приросту САТ на зміну положення тіла не мала статистичних розбіжностей $(p=0,07)$ у різних групах пацієнтів, а от характер розподілу різних реакцій продемонстрував певні суттєві розбіжності. У пацієнток із ГХ і супутньою ЗДА, на відміну від осіб без анеміі, спостерігали достовірне збільшення частоти реєстрації парадоксальної реакції САТ на зміну положення тіла $(20,3 \%$ проти 4,8\%, $=0,008)$, яка проявлялася зниженням рівня САТ на 3-й хвилині переходу з горизонтального у вертикальне положення. Збільшення частки таких пацієнтів відбувалося здебільшого за рахунок зменшення частки нормальної реакції. Остання визначалась як приріст величини САТ > 10 мм рт. ст. від вихідної величини. Інтерпретуючи отримані дані, можливо дійти висновку про суттєве порушення стану барорефлекторної регуляції САТ у жінок із АГ і супутньою ЗДА, зростання у цих пацієнтів частоти реєстрації парадоксальної реакції та, виходячи 3 цього, про підвищення частоти розвитку ортостатичної гіпотензії в даної категорії хворих.

Результати аналізу добової регуляції АТ у пацієнток із ГХ залежно від тяжкості супутньої ЗДА (табл. 2) продемонстрували, що в пацієнток із легкою ЗДА, на відміну від хворих без анемії, спостерігали суттєве зростання величини САТ_ден. $\quad(\mathrm{p}=0,039), \quad$ САТ_ніч. $\quad(\mathrm{p}=0,019)$, ПАТ_ніч. $(\mathrm{p}=0,047)$. Крім того, у цих пацієнток визначали достовірне зростання частоти реєстрації парадоксальної реакції у відповідь на зміну положення тіла $(21,4$ \% проти 4,8 \%, $\mathrm{p}=0,009)$.

У пацієнток із помірною ЗДА, крім відмічених змін, реєстрували додаткове збільшення величини САТ_доб. $(\mathrm{p}=0,036)$, ШРП САТ $(\mathrm{p}=0,009)$, ІЧ САТТ $(\mathrm{p}=0,024)$, ДАТ ніч. $(\mathrm{p}=0,033)$ i IB ДАТ_ніч. $(\mathrm{p}=0,024)$. Крім того, порівняно 3 пацієнтками з легкою ЗДА, у цих жінок реєстрували суттєве збільшення IB САТ_ніч. $(\mathrm{p}=0,028)$, IB ДАТ_ніч. $(\mathrm{p}=0,021)$ і ШРП САТ $(\mathrm{p}=0,011)$. Таким чином, тяжкість супутньої анемії, певним чином, асоційована з більш суттєвими порушеннями циркадного профілю АТ. Останнє характеризується зростанням величини САТ протягом доби і періоду його неконтрольованості, ДАТ у нічній час, нічної варіабельності САТ і ДАТ та швидкості ранкового зростання САТ.

Результати аналізу циркадної регуляції АТ залежно від тривалості анемічного анамнезу свідчили про наявність певного зворотного зв'язку між тривалістю супутньої ЗДА і порушеннями циркадної регуляції АТ. Так, саме в пацієнтів із нетривалим анемічним (до 10 років) анамнезом визначали більш переконливі порушення добової регуляції АТ, що характеризувалося зростанням величини САТ_ніч. $(\mathrm{p}=0,022)$, ДАТ_доб. $(\mathrm{p}=0,043)$, ПАТ_ніч. $(\mathrm{p}=0,031)$, ІВ САТ_ден. $(\mathrm{p}=0,039)$ і ІЧ $\mathrm{CAT}(\mathrm{p}=0,047)$ у цій групі порівняно 3 пацієнтами без анемії. Вищезазначені зміни не визначались у пацієнток із тривалим анемічним анамнезом (> 10 років).

Дані аналізу циркадної регуляції АТ залежно від тривалості анемічного анамнезу продемонстрували аналогічні виявленим раніше (табл. 1-2) змінам у групах пацієнтів із супутньою ЗДА. Натомість привертали увагу певні статистичні відмінності в групах пацієнтів із різною тривалістю ЗДА. Так, абсолютно неочікуваним виявився факт більш переконливого порушення циркадної регуляції АТ саме в пацієнтів із нетривалим анемічним анамнезом (до 10 років), що характеризувалося додатковим збільшенням величини САТ_ніч. $\quad(p=0,022)$, ДАТ_доб. $\quad(p=0,043)$, 
Таблиця 1

Характер циркадної та вегетативної регуляції артеріального тиску в жінок із гіпертонічною хворобою залежно від наявності супутньої залізодефіцитної анемії

\begin{tabular}{|c|c|c|c|}
\hline \multirow[b]{2}{*}{ Показники добового моніторування } & \multicolumn{2}{|c|}{ Клінічні групи } & \multirow[b]{2}{*}{$P$} \\
\hline & $\begin{array}{c}\text { ГХ без супутньої ЗДА } \\
(\mathrm{n}=62)\end{array}$ & $\begin{array}{c}\text { ГХ з супутньою ЗДА } \\
(\mathrm{n}=79)\end{array}$ & \\
\hline САТ_доб., мм рт. ст. & $146(141 ; 156)$ & $153(144 ; 160)$ & 0,022 \\
\hline САТ_ден., мм рт. ст. & $151(145 ; 161)$ & $157(150 ; 163)$ & 0,020 \\
\hline СAT_ніч., мм рт. ст. & $139(132 ; 149)$ & $146(136 ; 153)$ & 0,029 \\
\hline ДАТ_доб., мм рт. ст. & $90(82 ; 94)$ & $92(86 ; 96)$ & 0,15 \\
\hline ДАТ_ден., мм рт. ст. & $95(87 ; 98)$ & $97(90 ; 101)$ & 0,10 \\
\hline ДАТ_ніч., мм рт. ст. & $81(70 ; 87)$ & $84(77 ; 89)$ & 0,041 \\
\hline ПАТ_доб., мм рт. ст. & $60(54 ; 65)$ & $61(55 ; 68)$ & 0,26 \\
\hline ПАТ_ден., мм рт. ст. & $60(54 ; 64)$ & $60(55 ; 66)$ & 0,14 \\
\hline ПАТ_ніч., мм рт. ст. & $60(53 ; 67)$ & $64(56 ; 69)$ & 0,038 \\
\hline IB CAT_ден., мм рт. ст. & $15(13 ; 18)$ & $18(15 ; 21)$ & 0,029 \\
\hline IB CAT_ніч., мм рт. ст. & $15(11 ; 18)$ & $15(12 ; 20)$ & 0,71 \\
\hline IВ ДАТ_ден., мм рт. ст. & $12(10 ; 14)$ & $12(10 ; 15)$ & 0,65 \\
\hline IВ ДАТ_ніч., мм рт. ст. & $9(8 ; 13)$ & $11(8 ; 14)$ & 0,26 \\
\hline ДІ САТ, \% & $7,7(4,1 ; 13,1)$ & $5,3(1,8 ; 12,0)$ & 0,14 \\
\hline ДІ ДАТ, \% & $14,2(9,5 ; 20,6)$ & $10,1(7,2 ; 19,1)$ & 0,09 \\
\hline РП САТ, мм рт. ст. & $60(53 ; 65)$ & $59(50 ; 65)$ & 0,56 \\
\hline РП ДАТ, мм рт. ст. & $37(32 ; 41)$ & $36(31 ; 41)$ & 0,48 \\
\hline ШРП САТ, мм рт. ст./год & $9(8 ; 13)$ & $12(9 ; 16)$ & 0,042 \\
\hline ШРП ДАТ, мм рт. ст./год & $6(4 ; 8)$ & $7(5 ; 8)$ & 0,52 \\
\hline IЧ CAT, \% & $17(12 ; 22)$ & $21(15 ; 26)$ & 0,003 \\
\hline ІЧ ДАТ, \% & $19(14 ; 25)$ & $20(14 ; 25)$ & 0,78 \\
\hline Динаміка САТ на ОП, мм рт. ст. & $4(-6 ; 15)$ & $2(-9 ; 12)$ & 0,07 \\
\hline \multicolumn{4}{|c|}{ Характер реакції САТ на активну ортостатичну пробу (3-тя хвилина) } \\
\hline Нормальна & $24(38,7 \%)$ & $21(26,6 \%)$ & 0,12 \\
\hline Знижена & $35(56,5 \%)$ & $42(53,5 \%)$ & 0,69 \\
\hline Парадоксальна & $3(4,8 \%)$ & $16(20,3 \%)$ & 0,008 \\
\hline
\end{tabular}

Примітка (тут і в наступних таблицях). 1. САТ_доб., САТ_ден. і САТ_ніч. - середньо-добовий, середньо-денний і середньо-нічний систолічний артеріальний тиск; ДАТ_доб., ДАТ_ден. і ДАТ_ніч. - середньо-добовий, середньоденний і середньо-нічний діастолічний артеріальний тиск; ПАТ_доб., ПАТ_ден. і ПАТ_ніч. - середньо-добовий, середньо-денний і середньо-нічний пульсовий артеріальний тиск; IB CAT і IB ДАТ - індекс варіабельності систолічного і діастолічного артеріального тиску; ДІ САТ і ДІ ДАТ - добовий індекс систолічного і діастолічного артеріального тиску; РП САТ і РП ДАТ - ранковий приріст систолічного і діастолічного артеріального тиску; ШРП САТ і ШРП ДАТ швидкість ранкового приросту систолічного і діастолічного артеріального тиску; ІЧ САТ і ІЧ ДАТ - індекс часу систолічного і діастолічного артеріального тиску; ОП - ортостатична проба; 2. Достовірність різниці результатів між групами розрахована за критерієм Манна-Уітні (U-критерій), а відсотків - за критерієм $\chi^{2}$ 
Таблиця 2

Характер циркадної та вегетативної регуляції артеріального тиску і частоти серцевих скорочень у жінок із гіпертонічною хворобою залежно від тяжкості супутньої анемії

\begin{tabular}{|c|c|c|c|c|c|c|}
\hline & \multicolumn{3}{|c|}{ Клінічні групи } & \multirow{3}{*}{$\mathrm{P} 1-2$} & \multirow{3}{*}{$\mathrm{P} 1-3$} & \multirow{3}{*}{$\mathrm{P} 2-3$} \\
\hline & $\begin{array}{c}\text { ГХ без супутньої } \\
\text { ЗДА }(\mathrm{n}=62)\end{array}$ & $\begin{array}{c}\text { ГХ з супутньою } \\
\text { ЗДА І стадії } \\
(\mathrm{n}=42) \\
\end{array}$ & $\begin{array}{c}\text { ГХ з супутньою } \\
\text { ЗДА ІІ стадії } \\
(\mathrm{n}=37) \\
\end{array}$ & & & \\
\hline & 1 & 2 & 3 & & & \\
\hline CAT_доб., мм рт. ст. & $146(141 ; 156)$ & $151(144 ; 160)$ & $154(145 ; 159)$ & 0,08 & 0,036 & 0,67 \\
\hline САТ_ден., мм рт. ст. & $151(145 ; 161)$ & $157(150 ; 162)$ & $157(150 ; 164)$ & 0,039 & 0,048 & 0,94 \\
\hline САТ_ніч., мм рт. ст. & $139(132 ; 149)$ & $145(136 ; 153)$ & $147(139 ; 152)$ & 0,019 & 0,017 & 0,38 \\
\hline ДАТ_доб., мм рт. ст. & $90(82 ; 94)$ & $92(85 ; 96)$ & $93(88 ; 95)$ & 0,09 & 0,08 & 0,98 \\
\hline ДАТ_ден., мм рт. ст. & $95(87 ; 98)$ & $97(89 ; 101)$ & $97(90 ; 99)$ & 0,11 & 0,27 & 0,66 \\
\hline ДАТ_ніч., мм рт. ст. & $81(70 ; 87)$ & $83(76 ; 91)$ & $86(84 ; 89)$ & 0,46 & 0,033 & 0,32 \\
\hline ПАТ_доб., мм рт. ст. & $60(54 ; 65)$ & $60(54 ; 68)$ & $63(58 ; 67)$ & 0,62 & 0,16 & 0,51 \\
\hline ПАТ_ден., мм рт. ст. & $60(54 ; 64)$ & $60(54 ; 66)$ & $61(57 ; 66)$ & 0,28 & 0,18 & 0,85 \\
\hline ПАТ_ніч., мм рт. ст. & $60(53 ; 67)$ & $64(58 ; 71)$ & $65(60 ; 73)$ & 0,047 & 0,036 & 0,32 \\
\hline IB CAT_ден., мм рт. ст. & $15(13 ; 18)$ & $18(17 ; 21)$ & $19(17 ; 24)$ & 0,15 & 0,17 & 0,98 \\
\hline IB CAT_ніч., мм рт. ст. & $15(11 ; 18)$ & $13(12 ; 16)$ & $17(12 ; 20)$ & 0,37 & 0,10 & 0,028 \\
\hline IВ ДАТ_ден., мм рт. ст. & $12(10 ; 14)$ & $13(11 ; 14)$ & $12(10 ; 15)$ & 0,43 & 0,95 & 0,44 \\
\hline IB ДАТ_ніч., мм рт. ст. & $9(8 ; 13)$ & $9(7 ; 13)$ & $12(9 ; 15)$ & 0,78 & 0,024 & 0,021 \\
\hline ДІ САТ, $\%$ & $7,7(4,1 ; 13,1)$ & $6,6(3,0 ; 12,2)$ & $4,8(2,6 ; 11,6)$ & 0,16 & 0,08 & 0,23 \\
\hline ДІ ДАТ, \% & $14,2(9,5 ; 20,6)$ & $11,3(8,1 ; 20,5)$ & $9,1(7,2 ; 16,3)$ & 0,10 & 0,06 & 0,28 \\
\hline РП САТ, мм рт. ст. & $60(53 ; 65)$ & $58(50 ; 61)$ & $59(50 ; 66)$ & 0,30 & 0,90 & 0,40 \\
\hline РП ДАТ, мм рт. ст. & $37(32 ; 41)$ & $35(31 ; 41)$ & $37(31 ; 41)$ & 0,45 & 0,69 & 0,75 \\
\hline $\begin{array}{l}\text { ШРП САТ, мм рт. ст./ } \\
\text { год }\end{array}$ & $9(8 ; 13)$ & $10(10 ; 17)$ & $14(12 ; 15)$ & 0,38 & 0,009 & 0,011 \\
\hline $\begin{array}{c}\text { ШРП ДАТ, мм рт. ст./ } \\
\text { год }\end{array}$ & $6(4 ; 8)$ & $7(5 ; 9)$ & $7(5 ; 8)$ & 0,43 & 0,79 & 0,62 \\
\hline ІЧ САТ, \% & $17(12 ; 22)$ & $20(13 ; 24)$ & $21(15 ; 25)$ & 0,14 & 0,024 & 0,42 \\
\hline ІЧ ДАТ, \% & $19(14 ; 25)$ & $19(12 ; 23)$ & $20(14 ; 26)$ & 0,89 & 0,19 & 0,76 \\
\hline $\begin{array}{c}\text { Динаміка САТ на ОП, } \\
\text { мм рт. ст. } \\
\end{array}$ & $4(-6 ; 15)$ & $2(-8 ; 13)$ & $3(-9 ; 10)$ & 0,16 & 0,20 & 0,64 \\
\hline & ктер реакції САТ & ктивну ортостат & пробу (3-тя хви & & & \\
\hline Нормальна & $24(38,7 \%)$ & $12(28,6 \%)$ & $9(24,3 \%)$ & 0,28 & 0,14 & 0,67 \\
\hline Знижена & $35(56,5 \%)$ & $21(50,0 \%)$ & $21(56,8 \%)$ & 0,51 & 0,97 & 0,54 \\
\hline Парадоксальна & $3(4,8 \%)$ & $9(21,4 \%)$ & $7(18,9 \%)$ & 0,009 & 0,024 & 0,78 \\
\hline ЧСС_ден. & $72(67 ; 79)$ & $78(72 ; 88)$ & $79(74 ; 82)$ & $\begin{array}{c}0,000 \\
6 \\
\end{array}$ & $\begin{array}{c}0,000 \\
5 \\
\end{array}$ & 0,71 \\
\hline ЧСС_ніч. & $64(59 ; 69)$ & $66(60 ; 69)$ & $65(61 ; 70)$ & 0,64 & 0,54 & 0,80 \\
\hline ЦІ & $1,12(1,02 ; 1,20)$ & $1,22(1,08 ; 1,34)$ & $1,19(1,11 ; 1,32)$ & 0,001 & 0,017 & 0,60 \\
\hline
\end{tabular}

Примітка. 1. Достовірність різниці показників розрахована за допомогою рангового дисперсійного аналізу (ANOVA) Краскела-Уолліса і медіанного тесту; 2. Достовірність різниці відсотків розрахована за критерієм $\chi^{2}$ 

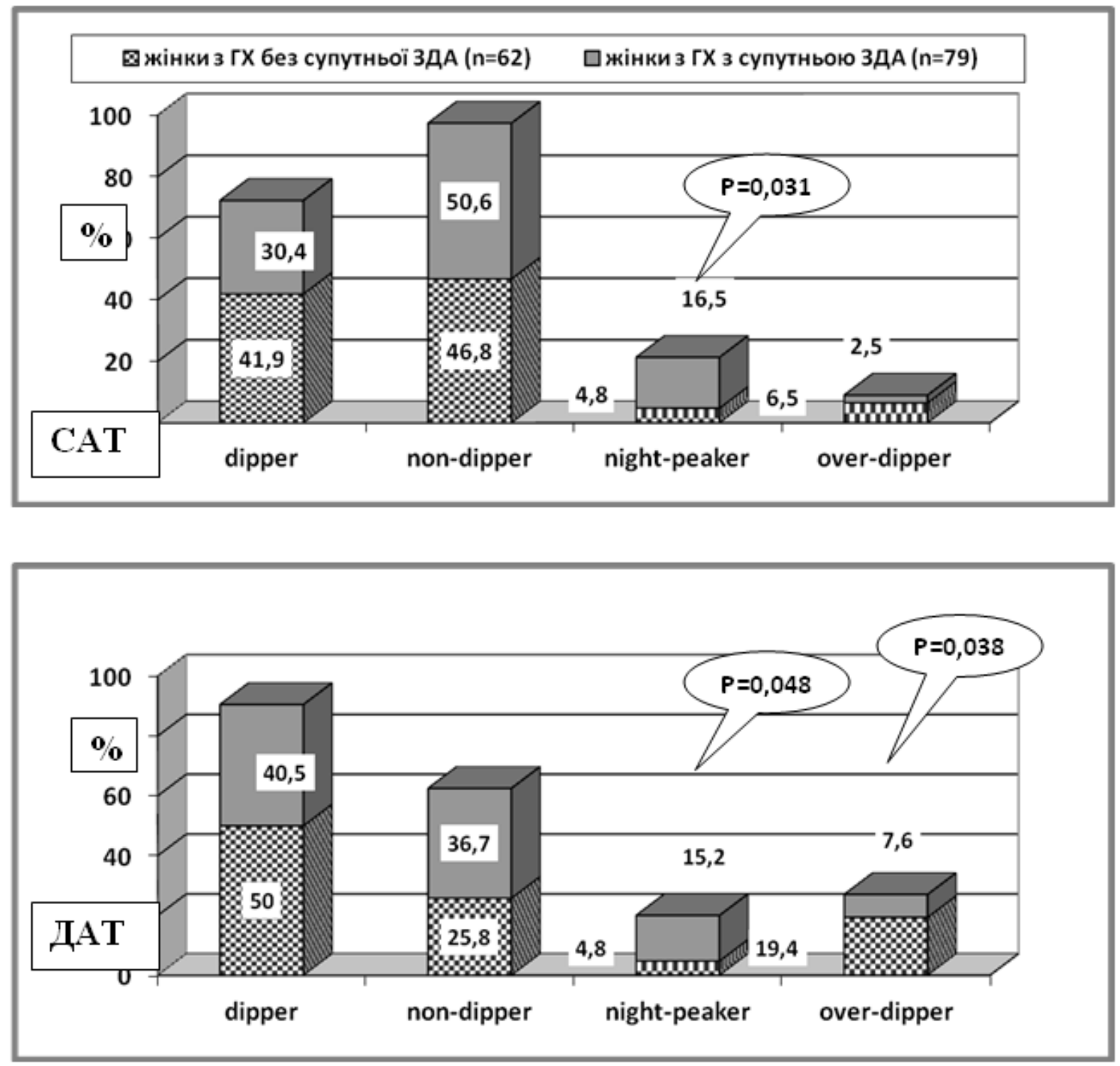

Рис. 1. Циркадний профіль систолічного і діастолічного артеріального тиску в жінок із гіпертонічною хворобою залежно від наявності супутньої залізодефіцитної анемії

Примітка. Достовірність різниці відсотків між групами розрахована за критерієм $\chi^{2}$

ПАТ_ніч. (p=0,031), ІВ САТ_ден. $(\mathrm{p}=0,039)$ і ІЧ $\operatorname{CAT}(p=0,047)$ у цій групі порівняно з пацієнтами без анемії. При цьому спостерігалось, що вищезазначені зміни не визначались у пацієнтів із тривалим анемічним анамнезом (> 10 років). 3 іншого боку, привертало увагу, що в жінок із тривалим анемічним порівняно 3 пацієнтками 3 анемічним анамнезом до 10 років, реєстрували лише достовірне збільшення величини РП САТ $(\mathrm{p}=0,039)$, що ніяким чином не підтверджувалося логічним зв'язком із попередньо наведеними даними.

Аналіз типу циркадного профілю САТ і ДАТ у різних групах залежно від наявності супутньої ЗДА (рис. 1) свідчив, що в переважної більшості обстежених реєстрували циркадний профіль dipper (від 30,4 \% до 50,0 \% обстежених) i non-dipper (від 25,8 \% до 50,6 \%). Такі патологічні типи добової регуляції АТ як night-peaker спостерігали не частіше ніж у $16,5 \%$, a over-dipper - у $19,4 \%$ випадків.
При оцінці циркадного профілю САТ привертало увагу, що нормальний тип dipper реєстрували практично в третини пацієнтів (41,9 \% i $30,4$ \% відповідно, $\mathrm{p}=0,15)$, у той час як при оцінці ДАТ - майже в половини випадків (50,0\% і 40,5 \% відповідно, $\mathrm{p}=0,26)$. Патологічний тип non-dipper для САТ реєструвався практично в половині випадків (46,8 \% і 50,6 \% відповідно, $\mathrm{p}=0,64)$ і для ДАТ - приблизно в третині пацієнтів $(25,8 \%$ і 36,7 \% відповідно, p=0,17). Подібну дисоціацію між показниками циркадного профілю САТ і ДАТ, на наш погляд, можливо пояснити різними нейрогуморальними механізмами регуляції САТ і ДАТ протягом доби.

Суттєве зростання частоти реєстрації патологічного профілю night-peaker як для САТ $(16,5 \%$ проти $4,8 \%, \mathrm{p}=0,031)$, так і для ДАТ $(15,2 \%$ проти $4,8 \%, p=0,048)$ у пацієнтів із супутньою ЗДА відбувалося за рахунок відносного зменшення частоти реєстрації нормального про- 

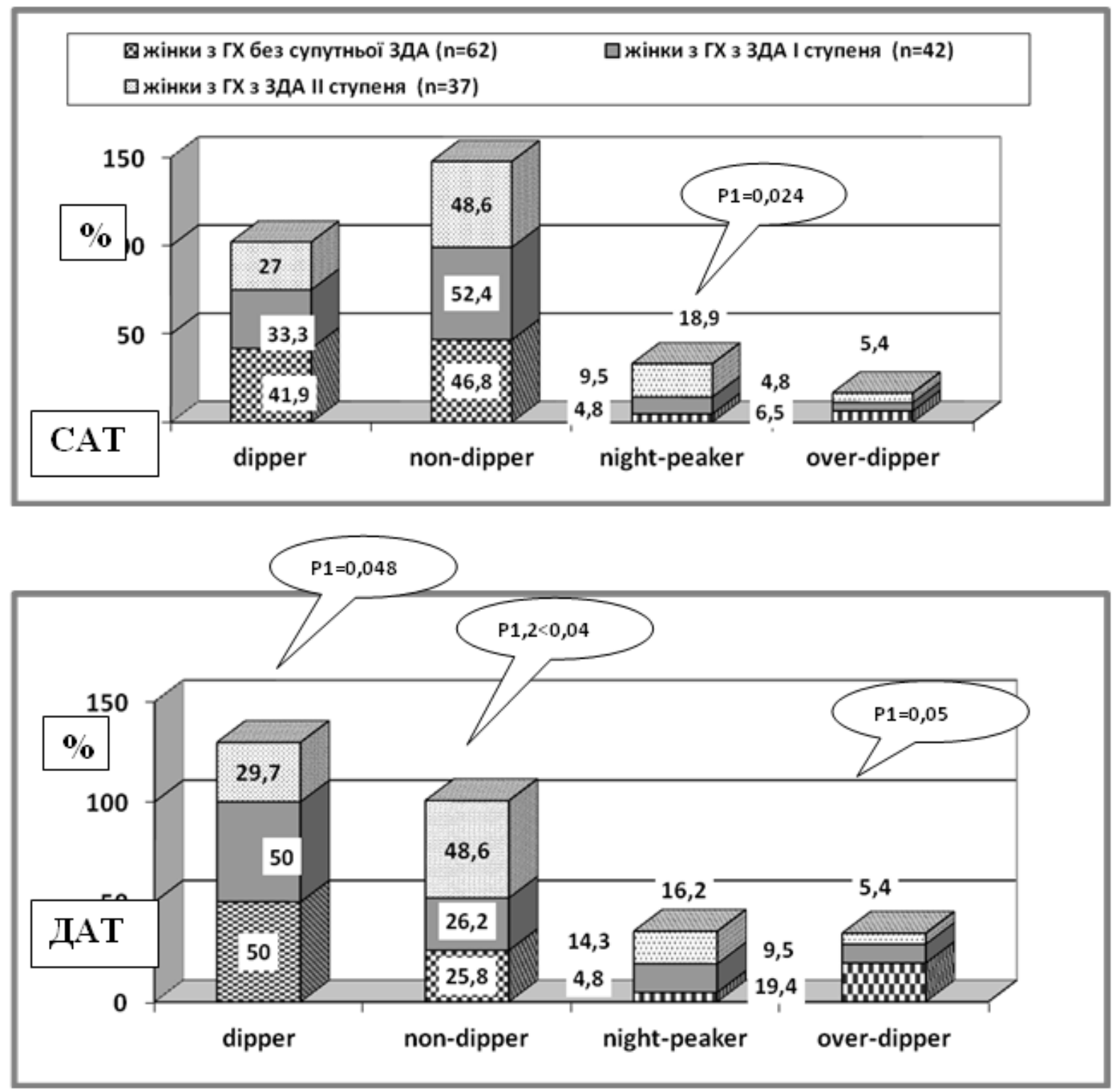

Рис. 2. Циркадний профіль систолічного і діастолічного артеріального тиску в жінок із гіпертонічною хворобою залежно від тяжкості супутньої залізодефіцитної анемії

Примітка. 1. Достовірність різниці відсотків між групами розрахована за критерієм $\chi^{2} ; 2$. p1 - достовірність по відношенню до групи без анемії, p2- по відношенню до групи з анемією I ступеня

філю dipper i патологічного типу over-dipper (7,6 \% проти 19,4 \%, p=0,03 8) лише для ДАТ.

Аналіз характеру циркадних типів АТ залежно від тяжкості супутньої ЗДА (рис. 2) свідчив, що в пацієнток із легкою ЗДА: 1) відсутня суттєва різниця в розподілі типів dipper i non-dipper порівняно 3 пацієнтами без анемії; 2) спостерігається тенденція до збільшення частоти реєстрації типу night-peaker i зменшення типу over-dipper порівняно $з$ пацієнтами без анемії як при оцінці динаміки САТ,так і ДАТ.

У пацієнток із помірною ЗДА вищезазначені тенденції набували статистичної значимості як по відношенню до осіб із легкою, так і осіб без анемії. Так, суттєве збільшення частоти реєстрації типу night-peaker (18,9 \% проти 4,8\%, $\mathrm{p}=0,024)$ при оцінці динаміки САТ і зменшення частоти реєстрації типу dipper (29,7 \% проти
$50,0 \%, \mathrm{p}=0,048)$ i over-dipper $(5,4 \%$ проти 19 $19,4 \%, \mathrm{p}=0,05)$ при оцінці ДАТ визначали по відношенню до пацієнтів без анемії. У той же час суттєве збільшення частоти реєстрації типу поndipper (48,6 \% проти 25,8-26,2 \%, р<0,04) при оцінці ДАТ спостерігали по відношенню до обох груп пацієнтів.

Таким чином, динаміка ДАТ характеризується зменшенням частоти реєстрації типу dipper i over-dipper та збільшенням - типу non-dipper, a динаміка САТ - збільшенням частоти реєстрації типу night-peaker. У цілому же тяжкість супутньої ЗДА у пацієнтів із ГХ асоціюється з суттєвими змінами циркадного профілю АТ.

Аналіз циркадного профілю АТ залежно від тривалості супутньої анемії (рис. 3) продемонстрував відсутність прямого зв'язку між тривалістю супутньої ЗДА і суттєвими змінами циркадно- 

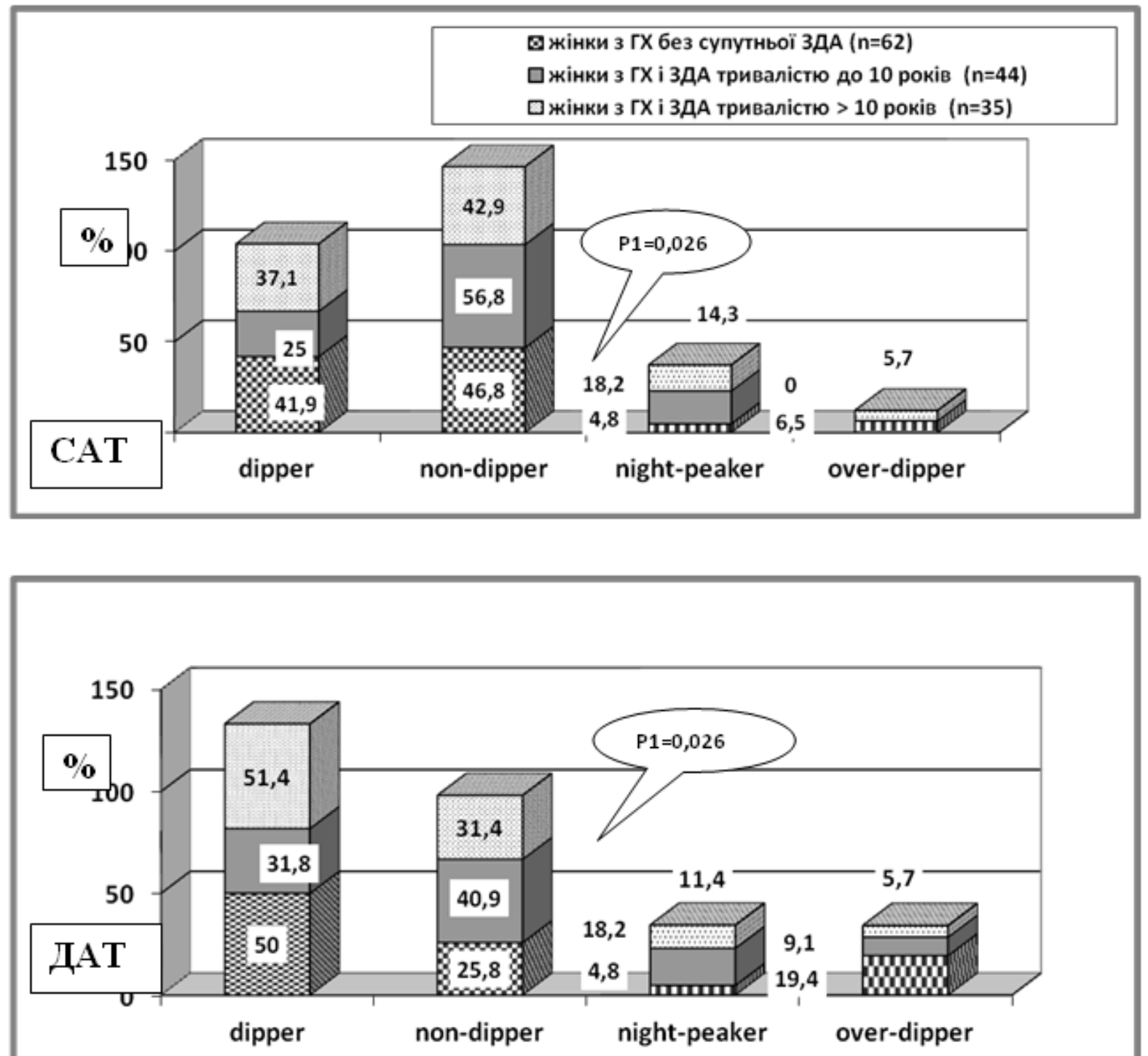

Рис. 3. Циркадний профіль систолічного і діастолічного артеріального тиску в жінок із гіпертонічною хворобою залежно від тривалості анемічного анамнезу

Примітка. 1. Достовірність різниці відсотків між групами розрахована за критерієм $\chi^{2} ; 2$. p1 - достовірність по відношенню до групи без анемії

го профілю САТ і ДАТ. Проте в групі пацієнтів із анемічним анамнезом до 10 років спостерігали достовірне зростання частоти реєстрації циркадного профілю night-peaker порівняно 3 хворими без анемії.

\section{Висновки}

1. Наявність супутньої залізодефіцитної анемії в пацієнток із гіпертонічною хворобою асоціюється зі збільшенням рівня систолічного артеріального тиску за всі періоди доби, діастолічного артеріального тиску та пульсового артеріального тиску в нічний час, варіабельності систолічного артеріального тиску в денний час і швидкості приросту систолічного артеріального тиску в ранковий час, зростанням частоти реєстрації парадоксальної реакції на ортостатичну пробу i патологічного профілю night-peaker при оцінці як систолічного артеріального тиску, так і діастолічного артеріального тиску та зменшенням патоло- гічного профілю over-dipper при оцінці динаміки діастолічного артеріального тиску.

2. Тяжкість супутньої залізодефіцитної анемії у жінок із гіпертонічною хворобою асоціюється зі зростанням величини систолічного артеріального тиску упродовж доби, діастолічного артеріального тиску в нічній час, нічної варіабельності систолічного артеріального тиску і діастолічного артеріального тиску, швидкості ранкового зростання систолічного артеріального тиску, зменшенням частоти реєстрації типу dipper i overdipper та збільшенням - non-dipper при оцінці діастолічного артеріального тиску i night-peaker при оцінці систолічного артеріального тиску.

Перспективи подальших досліджень. Подальші дослідження доцільно спрямувати на вивчення особливостей перебігу гіпертонічної хвороби, поєднаної з залізодефіцитною анемією та 
оцінці клінічної ефективності різних груп антигіпертензивних препаратів у цієї категорії хворих.

\section{Література}

1. Артеріальна гіпертензія. Оновлена та адаптована клінічна настанова, заснована на доказах (2012 рік): практичні рекомендації; проект / Робоча група 3 артеріальної гіпертензії Укр. асоц. кардіологів // Артериал. гипертензия. - 2012. - № 1. - С. 96-152.

2. Дворецкий Л.И. Железодефицитные анемии Л.И. Дворецкий. - М.: Ньюдиамед-Ао, 1998. - 37 с.

3. Лапач С.Н. Статистические методы в медико-биологических исследованиях с использованием Excel [2-е изд.] / С.Н. Лапач, А.В. Чубенко, П.Н. Бабич. - К.: Морион, 2001. $-408 \mathrm{c}$.

4. Реброва О.Ю. Статистический анализ медицинских данных. Применение пакета программ Statistica / О.Ю. Реброва. - М.: Медиа Сфера, 2006. - 312 с.
5. Серцево-судинні захворювання. Рекомендації з діагностики, профілактики та лікування / За ред. В.М. Коваленка, М.І. Лутая. - К.: МОРІОН, 2011. $408 \mathrm{c}$.

6. Уніфікований клінічний протокол первинної та вторинної (спеціалізованої) медичної допомоги. Залізодефіцитна анемія: наказ Міністерства охорони здоров'я України 02.11.15 № 709 // Нов. мед. и фарм. в Украине. - 2015. - № 15. - C. 33-34.

7. $2013 \mathrm{ESH} / \mathrm{ESC}$ Guidelines for the management of arterial hypertension: The Task Force for the management of arterial hypertension of the European Society of Hypertension (ESH) and of the European Society of Cardiology (ESC) / G. Mancia, R. Fagard, K. Narkiewicz [et al.] // J. of Hypertension. - 2013. - Vol. 31, Iss. 7. - P. 1281-1357.

\section{ХАРАКТЕР ЦИРКАДНОЙ И ВЕГЕТАТИВНОЙ РЕГУЛЯЦИИ АРТЕРИАЛЬНОГО ДАВЛЕНИЯ У ЖЕНЩИН С ГИПЕРТОНИЧЕСКОЙ БОЛЕЗНЬЮ В ЗАВИСИМОСТИ ОТ НАЛИЧИЯ СОПУТСТВУЮЩЕЙ ЖЕЛЕЗОДЕФИЦИТНОЙ АНЕМИИ, ЕЁ ТЯЖЕСТИ И ДЛИТЕЛЬНОСТИ}

\section{С.О. Сулим}

Резюме. Обследована 141 женщина с гипертонической болезнью II стадии с и без сопутствующей железодефицитной анемией в воздасте от 54 до 87 лет. У пациенток изучали характер циркадной и вегетативной регуляции артериального давления (АД) в зависимости от наличия сопутствующей железодефицитной анемии, её тяжести и продолжительности. Проводился анализ результатов активной ортостатической пробы и суточного мониторирования АД с вычислением общеизвестных показателей. Выявлено, что наличие сопутствующей железодефицитной анемии и её тяжесть ассоциируются со значительными нарушениями суточной регуляции АД и его барорефлекторной регуляции. В свою очередь, не выявлено ассоциаций между длительностью сопутствующей анемии и нарушениями циркадной регуляции АД.

Ключевые слова: циркадная регуляция и циркадный профиль артериального давления, гипертоническая болезнь, железодефицитная анемия.

\section{NATURE OF CIRCADIAN AND AUTONOMIC REGULATION OF BLOOD PRESSURE IN WOMEN WITH ARTERIAL HYPERTENSION DEPENDING ON THE PRESENCE OF CONCOMITANT IRON DEFICIENCY ANEMIA, ITS SEVERITY AND DURATION}

\section{S.O. Sulym}

Abstract. One hundred and forty one women, aged 54-87 years old with arterial hypertension of stage II, with and without concomitant iron deficiency anemia were examined. Nature of circadian and autonomic regulation of blood pressure depending on the presence of concomitant iron deficiency anemia, its severity and duration were studied in the following patients. The results of active orthostatic test and daily monitoring of blood pressure with calculation of common indicators were analyzed. It was discovered that the presence of concomitant iron deficiency anemia and its severity in women with hypertension is associated with significant disorders in daily regulation of blood pressure and its baroreflex regulation. In turn, no significant associations were discovered between the duration of concomitant anemia and disorders of circadian regulation of blood pressure.

Key words: circadian regulation and circadian profile of blood pressure, arterial hypertension, iron deficiency anemia.

Pirogov National Medical University (Vinnytsia)

Рецензент - проф. Л.П. Сидорчук

Buk. Med. Herald. - 2016. - Vol. 20, № 3 (79). - P. 175-182

Надійшла до редакції 05.07.2016 року

(c) С.О. Сулим, 2016 